\title{
Negative sweat tests and cystic fibrosis
}

\author{
J. K. SARSFIELD and J. M. DAVIES* \\ From the Department of Paediatrics and Child Health, University of Leeds, and Seacroft Hospital, Leeds
}

\begin{abstract}
Sarsfield, J. K., and Davies, J. M. (1975). Archives of Disease in Childhood, 50, 463. Negative sweat tests and cystic fibrosis. Two brothers are described with chronic suppurative pulmonary disease. One has classical cystic fibrosis with complete pancreatic involvement and abnormal sweat test. The other had incomplete pancreatic disease with repeatedly normal sweat tests. The implications of a negative sweat test in patients with cystic fibrosis are discussed.
\end{abstract}

A positive sweat test is generally considered to be a sine qua non in the diagnosis of cystic fibrosis, but this is not essential using the diagnostic criteria of Di Sant'Agnese and Vidauretta (1960). Clinical manifestations of the disease usually result from disturbances of lung and pancreatic function which can be dissociated (Shwachman, 1972) and it is generally accepted that they can also vary in severity and age of appearance. The salty sweat secreted by patients suffering from the disease forms only part of a complex biochemical disorder which has a recessive mode of inheritance. The possibility exists that abnormal sweat electrolyte levels may not be universal (Cogswell, Risdon, and Taylor, 1974), and undue reliance on these may result in a missed diagnosis. In view of the mode of inheritance of the disease and the present trend towards small families, the majority of cases will appear only in a single member of a family, in which case the family history will give no diagnostic assistance.

This paper describes two brothers, one with classical cystic fibrosis, the other with partial clinical expression of the disease and a negative sweat test, and highlights possible diagnostic pitfalls which may occur in isolated cases.

\section{Case reports}

The two brothers were the only male offspring of white Caucasian parents whose marriage is nonconsanguineous. The other child is a girl with Down's syndrome (karyotype $47, \mathrm{XX}$ ) but with no symptoms of cystic fibrosis and a normal sweat test.

Case 1. The younger brother was born in July 1968 after a normal pregnancy and delivery. He

Received 12 November 1974.

^Present address: Department of Paediatrics, Scartho Road Hospital, Grimsby. presented in November 1970 after acute onset of a right lower lobe pneumonia. There was no previous history of chest trouble, but he had been noted to be small, and his height and weight on admission were below the 3rd centile for his age. Sputum culture revealed Staphylococcus aureus, but was negative for tubercle bacilli, and the Mantoux test was negative. Chest $x$-ray revealed a right lower lobe collapse-consolidation with mottled densities in the right upper lobe and left midzone. The response to antibiotic therapy was poor, finger clubbing developed, and lung abscess formation was suspected. Bronchoscopy revealed no endobronchial obstruction. Progressive destruction of the right lung occurred and this was removed in March 1971; histological changes were compatible with those found in cystic fibrosis. The results of other investigations (Tables I and II), together with the subsequent clinical course of chronic chest infection and the appearance on chest $x$-ray of diffuse ring shadows and mottled densities, confirmed the diagnosis of classical cystic fibrosis.

Case 2. The elder brother was born in May 1966 after a normal pregnancy and delivery; his birthweight was $3180 \mathrm{~g}$ and the neonatal course uneventful. Although he was always small, he remained well until 1972, when he was referred to hospital with a 6-month history of chronic cough and green sputum, which had failed to respond to treatment with several antibiotics. His weight and height were below the 3rd centile and sputum culture grew Staph. aureus. Numerous crepitations were heard in the chest, and $x$-ray showed bilateral nodular mottling in all zones. The sweat tests were all normal (Table II). In spite of regular physiotherapy and antibiotics administered both systemically and by aerosol, his subsequent course was one of chronic cough and green sputum. His general condition deteriorated with failure to thrive and the development of severe pectus excavatum. The sputum was constantly ininfected with Staph. aureus, Pseudomonas pyocyanea, or Klebsiella organisms. Chest $x$-ray appearances deteriorated and showed widespread severe diffuse reticular 
TABLE I

General investigations

\begin{tabular}{|c|c|c|}
\hline & Case 1 & Case 2 \\
\hline $\begin{array}{l}\text { Haemoglobin (g/dl) } \\
\text { White blood cells/mm } \\
\text { Neutrophils }(\%) \\
\text { Lymphocytes }(\%) \\
\text { Monocytes }(\%) \\
\text { Faecal fat excretion in } 5 \mathrm{~d}(\mathrm{~g}) \\
\text { Stool tryptic activity } \\
\text { Mantoux test } \\
\text { Sputum culture } \\
\text { Sputum culture for acid-fast bacilli } \\
\text { Sputum haemosiderin } \\
\text { Serum immunoglobulins (mg/100 ml) } \\
\text { IgG } \\
\text { IgA } \\
\text { IgM } \\
\text { Serum C3 complement (mg/100 ml) } \\
\text { Serum } \alpha_{1} \text { - antitrypsin (screening test) } \\
\text { Serum autoimmune antibodies } \\
\text { Serum factor for inhibition of mussel cilia } \\
\text { Salivary electrolytes }\end{array}$ & 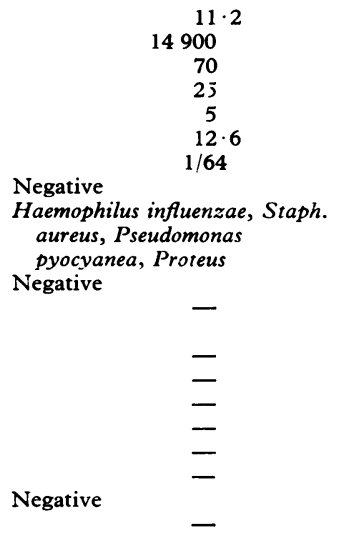 & $\begin{array}{lc} & 12 \cdot 7 \\
& 13300 \\
& 78 \\
& 18 \\
& 13 \cdot 5 \\
& 1 / 128 \\
\text { Negative } & \\
\text { Haemophilus } & \text { influenzae, Staph. } \\
\quad \text { aureus, Pseudomonas } \\
\text { pyocyanea, Klebsiella } \\
\text { Negative } & \\
\text { Not detected } & \\
& \\
& 1650 \\
& 130 \\
\text { Normal } & 70 \\
\text { None detected } & \\
\text { Negative } & \\
\text { Normal } & \end{array}$ \\
\hline
\end{tabular}

TABLE II

Sweat test results

\begin{tabular}{|c|c|c|c|c|}
\hline & \multirow{2}{*}{ Date } & \multicolumn{2}{|c|}{ Result (mEq/1) } & \multirow{2}{*}{ Method } \\
\hline & & $\mathrm{Na}+$ & $\mathrm{Cl}-$ & \\
\hline Case 1 & $\begin{array}{l}\text { Dec } 70 \\
\text { Dec } 70 \\
\text { Dec } 72 \\
\text { July } 72 \\
\text { July } 72\end{array}$ & $\begin{array}{l}60 \\
67 \\
60 \\
60 \\
78\end{array}$ & $\begin{array}{l}66 \\
56 \\
66 \\
68 \\
82\end{array}$ & $\begin{array}{l}\text { Pilocarpine iontophoresis } \\
\text { Pilocarpine iontophoresis } \\
\text { Pilocarpine iontophoresis } \\
\text { Pilocarpine iontophoresis } \\
\text { Thermal }\end{array}$ \\
\hline Case 2 & $\begin{array}{l}\text { Apr } 71 \\
\text { Sept } 72 \\
\text { Jan } 74\end{array}$ & $\begin{array}{r}4 \\
3 \\
14\end{array}$ & $\begin{array}{r}1 \\
16 \\
21\end{array}$ & $\begin{array}{l}\text { Pilocarpine iontophoresis } \\
\text { Pilocarpine iontophoresis } \\
\text { Pilocarpine iontophoresis }\end{array}$ \\
\hline
\end{tabular}

nodular mottling and hyperinflation (Fig.). He died in August 1974; permission for necropsy was not obtained.

Investigations. The results of the investigations on the younger brother, Case 1 , and the clinical course suggested the diagnosis of classical cystic fibrosis. Both the lung and pancreas were severely involved and reprated sweat tests (Table II) revealed salt levels within the diagnostic range obtained over many years by our laboratory (Mr A. E. Steel).

Sweat tests performed on the elder brother, Case 2, repeatedly yielded normal results; all the usual precautions reviewed by Gibson (1972) were observed to ensure the validity of these tests. Other investigations (Table I) excluded some rarer causes of chronic pulmonary suppurative disease, immune deficiency states, tuberculosis, haemosiderosis, $\alpha$-antitrypsin deficiency, and autoimmune diseases.

Pancreatic function tests were performed as described by Hadorn et al. (1968b), and the results are shown in Table III. The results for the younger brother with classical cystic fibrosis indicate severe pancreatic hypofunction. The elder brother, with a normal sweat test, had a normal trypsin output but a depressed amylase output and excessively low values for volume and bicarbonate. Unfortunately, it was impossible to estimate lipase, but both brothers had high levels of stool fat (Table I).

\section{Discussion}

Cystic fibrosis is the most likely diagnosis in these two brothers, especially the younger boy, Case 1, who had a positive sweat test. The diagnosis in the elder boy is less clear, but the chronic pulmonary involvement with a positive family history supported such a diagnosis. Pancreatic 


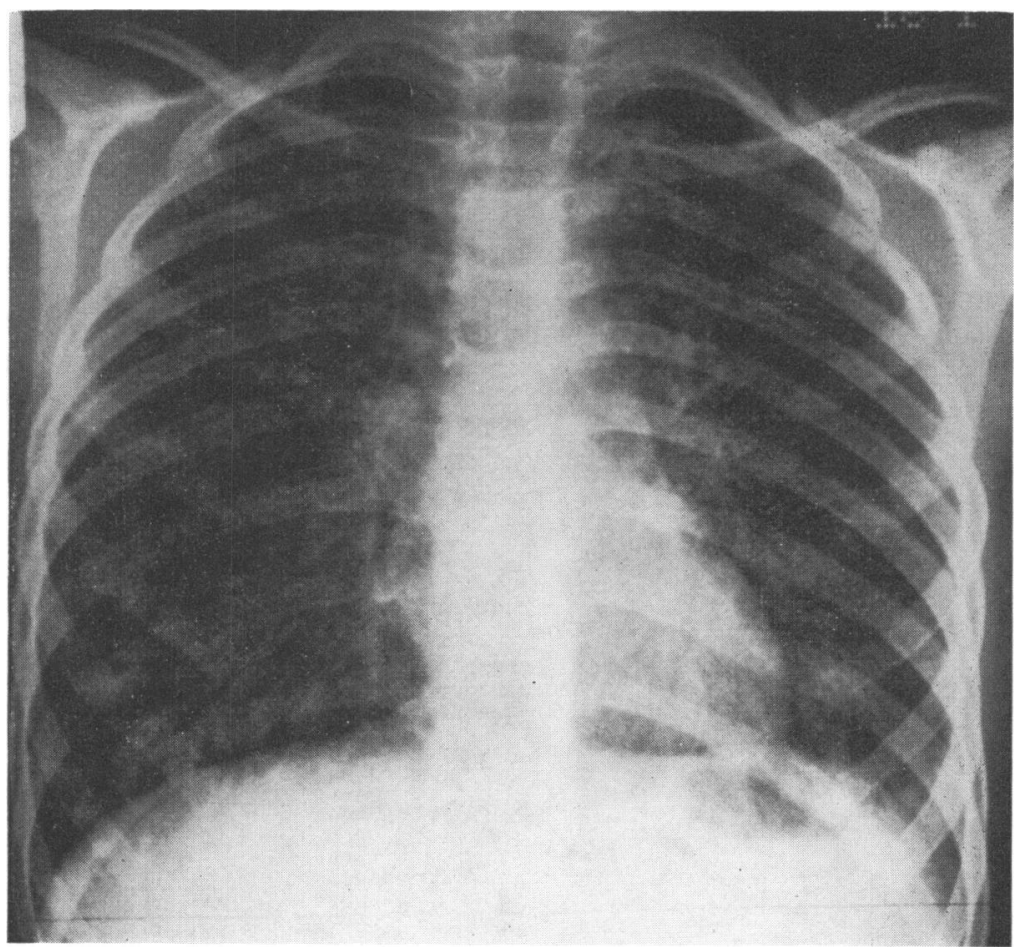

FIG.-Chest $\mathrm{x}$-ray of Case 2 showing hyperinflation, diffuse mottling, and ring shadows.

function tests in this older boy showed a similar pattern to that described by Hadorn et al. (1968a) in a group of children with cystic fibrosis who had a mean stool fat excretion of less than $5 \mathrm{~g} /$ day. The stimulated pancreatic secretions in this group were of a small volume and very low bicarbonate content; enzyme outputs were variable with values frequently above the normal mean.

The repeated negative sweat tests in Case 2 appear to confirm the concept that cystic fibrosis can exist with normal sweat electrolyte levels. This clinical variant is probably genotypically similar to the usual phenotype. The fact that the parents were not affected supports the generally accepted recessive mode of inheritance. Undue diagnostic reliance on the sweat test, especially when used for the exclusion of cystic fibrosis, may be misplaced.

One can speculate that the disease undiagnosed may be responsible for a proportion of recurrent cases of respiratory infection in infancy and early childhood. More effort is clearly required to define this complex disease, which may have more clinical and diagnostic variants than previously recognized.

TABLE III

Pancreatic function tests

\begin{tabular}{|c|c|c|c|c|}
\hline & Volume (ml) & $\begin{array}{l}\text { Bicarbonate } \\
\text { (mEq) }\end{array}$ & Trypsin (ug) & Amylase (IU) \\
\hline $\begin{array}{l}\text { Case } 1 \\
\text { Case } 2\end{array}$ & $\begin{array}{l}0.98 \\
0.60\end{array}$ & $\begin{array}{l}0.040 \\
0.012\end{array}$ & $\begin{array}{r}1 \cdot 1 \\
978 \cdot 0\end{array}$ & $\begin{array}{l}140 \\
170\end{array}$ \\
\hline $\begin{array}{l}\text { Normal values } \\
\text { Mean } \pm S D \\
\text { Range }\end{array}$ & $\begin{array}{l}3 \cdot 9 \pm 1 \cdot 5 \\
1 \cdot 8-8 \cdot 1\end{array}$ & $\begin{array}{l}0.19 \pm 0.08 \\
0.08-0.37\end{array}$ & $\begin{array}{l}788 \pm 549 \\
215-2170\end{array}$ & $\begin{array}{l}476 \pm 350 \\
302-2050\end{array}$ \\
\hline
\end{tabular}

Note: Total output of volume, bicarbonate, and enzymes per $\mathrm{kg}$ and per $50 \mathrm{~min}$.

*Normal values from Hadorn et al. (1968b). 
We are grateful to Dr. M. F. G. Buchanan for permission to publish these cases, and for advice; to Professor R. W. Smithells, and Drs. J. M. Littlewood and S. E. W. Smith for advice; and to Mr. A. E. Steel, who performed the sweat tests and chemical estimations of duodenal juice, and Dr. M. D'A. Crawfurd, who performed the cilia inhibition studies.

\section{REFBRENCES}

Cogswell, J. J., Risdon, R. A., and Taylor, B. (1974). Chronic suppurative lung disease in sisters, mimicking cystic fibrosis. Archives of Disease in Childhood, 49, 520.

Di Sant'Agnese, P. A., and Vidaurreta, A. M. (1960). Cystic fibrosis of the pancreas. Fournal of the American Medical Association, 172, 2065.
Gibson, L. E. (1972). Reliability of sweat tests in diagnosis of cystic fibrosis. Fournal of Pediatrics, 81, 193.

Hadorn, B., Johansen, P. G., and Anderson, C. M. (1968a). Pancreozymin secretin test of exocrine pancreatic function in cystic fibrosis and the significance of the result for the pathogenesis of the disease. Canadian Medical fournal, 98, 377.

Hadorn, B., Zoppi, G., Schmerling, D. H., Prader, A., McIntyre, I. and Anderson, C. M. (1968b). Quantitative assessment of pancreatic function in infants and children. Fournal of Pediatrics, 73, 39.

Shwachman, H. (1972). Cystic fibrosis. Pulmonary Disorders. Vol. 1 of Disorders of the Respiratory Tract in Children, 2nd ed., p.524. Ed. by E. L. Kendig, Jr. Saunders, London.

Correspondence to Dr. J. K. Sarsfield, Department of Paediatrics and Child Health, 27 Blundell Street, Leeds LS1 3ET. 